\title{
Research on the Status Quo of Continuing Education for Accountants in China's Colleges and Universities
}

\author{
Dahua Wang \\ Finance Department, Jilin Engineering Normal University, Changchun City, China \\ 894161521@qq.com
}

\begin{abstract}
Keywords: Accountants; Continuing education; Investigation of development status; Problems; Colleges and universities
\end{abstract}

\begin{abstract}
In recent ten years, China's accounting continuing education has achieved good results. The continuing education of Accountants in colleges and universities has also developed. The quality of accounting work has improved, but there are still many problems. This study conducted a questionnaire survey on the staff of financial departments in dozens of colleges and universities, such as Northeast Normal University, Jilin Engineering Normal University and so on, hoping to objectively and truly understand the status quo of the continuing education of Accountants in China's colleges and universities, expecting to find out the problems and put forward some suggestions for the continuing education of Accountants in Colleges and universities. It provides some references for the construction and improvement of the continuing education system of accountants.
\end{abstract}

\section{Introduction}

Since 1999, due to the adjustment of the national policy, the enrollment scale of colleges and universities has expanded year after year, and the amount of investment in colleges and universities has also increased [1]. Great changes have taken place in all aspects of the work of colleges and universities. The leap-forward development of colleges and universities, especially the rapid increase of educational input, makes the quality and quantity of accounting work in colleges and universities have also changed. On the one hand, the increasing income channels of colleges and universities make the financial work of universities more complicated. On the other hand, the corporatization of university system makes the financial objects of colleges and universities more and more extensive[2]. Accountants in Colleges and universities manage the huge funds of the colleges or universities and record all the economic and business matters of theml. Their professional quality and theoretical level directly affect the quality of accounting information, and indirectly affect the leadership decision-making and the development direction of the colleges and universities. The changes of accounting work in colleges and universities require the accountants to keep on learning, improve their professional skills and meet the needs of financial work in colleges and universities [3]. Therefore, continuing education of accountants plays an important role in improving the professional ability of accountants.

\section{Investigation on the Continuing Education for Accountants in Colleges and Universities}

It is understood that the continuing education of Accountants in China's colleges and universities is mainly two ways: one is network education, the other is face-to-face education [4]. In general, face-to-face education is organized and arranged by the financial department of the government. Accountants apply for face-to-face education by themselves. Face-to-face education is provided by training institutions appointed by the financial section and taught according to training materials. In addition, some financial departments in colleges and universities also employ some experts to make lectures for their accountants. The training time is usually set by the financial department of the government within the period of two or three days, or continuous weeks of training, a half-day weekly time. 
In order to accurately understand the status quo of the continuing education of Accountants in China's universities and objectively analyze the existing problems and causes, the research group conducted a questionnaire survey on the continuing education of accountants in some colleges and universities. A total of 300 questionnaires were distributed and 270 were recovered, of which 261 were valid questionnaires, accounting for $87 \%$ of the total. The survey covers dozens of universities, including Jilin University, Northeast Normal University, Jilin Engineer Normal University and other universities, including top universities and regular universities. The respondents are all accountants who are officially on-the-job in colleges and universities. Questionnaire is divided into two parts, totaling 15 questions. The first part of the questionnaire consists of five questions, including the basic information of the respondents, including their gender, age, education, professional titles, years of financial work, etc. The second part contains 10 questions, mainly investigating the status quo and views of the continuing education of Accountants in colleges and universities.

Demographical Characteristics of Respondents. The financial personnel in colleges and universities are mainly women, accounting for $75.1 \%$ of the total (shown in Table 1). The age of the respondents mainly concentrated in 31-50 years old, accounting for more than $69 \%$ of the respondents, indicating that with the reform of the education system in recent years, a large number of accounting practitioners have been introduced into colleges and universities, which makes the ranks of accounting practitioners younger. More than $69 \%$ of the respondents have undergraduate education, indicating that in recent years, China's accounting education have been made a great achievements. 90\% of the respondents have worked in finance for more than six years. Most of them are experienced, but they are also easy to satisfy the current situation and stagnate, indicating poor liquidity of financial personnel. In the term of professional titles, sub-accountant and others accounts for more than $46 \% .39 .8 \%$ of the accountant, only $13.4 \%$ of the personnel with senior accountant, indicating that there is a relatively lack of high-level accounting managers in China's colleges and universities.

From the analysis of the basic information of the respondents, we can draw the following conclusions: their age, educational background, professional titles cover a wide range, and their work experience, especially financial accounting work experience is relatively rich. They have a personal experience of the professional ability at different levels in actual work of accountants, and have personal experience and feelings about continuing education. Some problems reflected in this survey are more representative. 
Table 1 Demographical characteristics of respondents

\begin{tabular}{|c|c|c|c|}
\hline Characteristic & Frequency & $\%$ & $\mathrm{CF}(\%)$ \\
\hline \multicolumn{4}{|l|}{ Gender } \\
\hline Male & 65 & 24.9 & 24.9 \\
\hline Female & 196 & 75.1 & 100 \\
\hline \multicolumn{4}{|l|}{ Age } \\
\hline Under 30 & 35 & 13.4 & 13.4 \\
\hline $31-40$ & 68 & 26.1 & 39.5 \\
\hline $41-50$ & 113 & 43.3 & 82.8 \\
\hline More than 50 & 45 & 17.2 & 100 \\
\hline \multicolumn{4}{|l|}{ Education } \\
\hline Below junior college & 10 & 3.8 & 3.8 \\
\hline Junior college & 70 & 26.8 & 30.6 \\
\hline University & 139 & 53.3 & 83.9 \\
\hline Postgraduate & 42 & 16.1 & 100 \\
\hline \multicolumn{4}{|c|}{ Working experience in Finance } \\
\hline Under 5 years & 25 & 9.6 & 9.6 \\
\hline $6-15$ years & 91 & 34.9 & 44.5 \\
\hline 16-30 years & 129 & 49.4 & 93.9 \\
\hline More than 31 years & 16 & 6.1 & 100 \\
\hline \multicolumn{4}{|l|}{ Professional titles } \\
\hline Sub-accountant & 58 & 22.2 & 22.2 \\
\hline Accountant & 104 & 39.8 & 62 \\
\hline Senior accountant & 35 & 13.4 & 75.4 \\
\hline Others & 64 & 24.6 & 100 \\
\hline
\end{tabular}

Survey Results. According to the results of the questionnaire, the form and content of the continuing education of Accountants in colleges and universities are relatively sample. The teaching method is mainly the traditional classroom teaching, and the examination is mainly the open-book examination (shown in Table 2). The main channel continuing education for accountants in colleges and universities is to attend face-to-face training courses (up to $78.5 \%$ ), while only $21.5 \%$ of them take online courses. They generally believe that there are few opportunities for continuing education and less opportunities for high-quality and high-level continuing education. The content of continuing education is mainly the latest regulations issued by the state $(55.6 \%)$, but accountants are more concerned about the knowledge directly related to their jobs (only 6.1\%). The form of teaching has changed. Experts have been invited to lecture, and the case teaching and hot spot interaction have been adopted. However, traditional classroom teaching is still the main pattern (73.2\%). Teachers teach knowledge step by step according to the textbooks, and the trainees are not interested. Examination is a mere formality, and the proportion of open book examination is as high as $83.9 \%$. 
Table 2 Investigation on continuing education of respondents

\begin{tabular}{|c|l|c|c|c|}
\hline \multicolumn{1}{|c|}{ Subject } & Content & Frequency & $\%$ & CF (\%) \\
\hline \multirow{4}{*}{ Educational channel } & Face-to-face training courses & 205 & 78.5 & 78.5 \\
\cline { 2 - 5 } & Online courses & 41 & 15.7 & 94.2 \\
\cline { 2 - 5 } & Others & 15 & 5.8 & 100 \\
\hline \multirow{5}{*}{ Educational contents } & Latest laws and regulations & 145 & 55.6 & 55.6 \\
\cline { 2 - 5 } & Relevate case analysis & 24 & 9.2 & 64.8 \\
\cline { 2 - 5 } & Theoretical knowledge & 76 & 29.1 & 93.9 \\
\cline { 2 - 5 } & $\begin{array}{l}\text { Knowledge related to one's } \\
\text { Own work }\end{array}$ & 16 & 6.1 & 100 \\
\hline \multirow{5}{*}{ Assessment methods pattern } & Case study & 22 & 8.4 & 8.4 \\
\cline { 2 - 5 } & Classroom teaching & 191 & 73.2 & 81.6 \\
\cline { 2 - 5 } & Seminar & 71 & 15.7 & 97.3 \\
\cline { 2 - 5 } & Others & 27 & 2.7 & 100 \\
\cline { 2 - 5 } & Professional work check & 219 & 83.9 & 10.3 \\
\cline { 2 - 5 } & Open-book examination & 15 & 5.8 & 100 \\
\cline { 2 - 5 } & Closed-book examination & & & \\
\hline
\end{tabular}

The survey found that the acceptance degree of continuing education was not high among college accountants (shown in Table 3). As for the content of education, 47.5\% thought it was "neutral" and $32.4 \%$ thought it was "disagree"; only $2.6 \%$ thought it was "novel" and "diversified" in the current form of teaching; only $10.5 \%$ was satisfied with the quality of continuing education teachers; $43.5 \%$ believe that the current assessment of continuing education is unscientific and unrational. Through the usual informal interviews, we find that the demand for continuing education is still very high, and respondents generally hope to strengthen continuing education, get more training opportunities and time, and expect that the content and form of continuing education for accountants will be more diversified, so that they can have more independent choices.

Table 3 Evaluation of current continuing education of accountants by respondents

\begin{tabular}{|l|c|c|c|c|c|}
\hline \multicolumn{1}{|c|}{ Subject } & $\begin{array}{c}\text { Strongly } \\
\text { disagree }\end{array}$ & Disagree & Neutral & Agree & $\begin{array}{c}\text { Strongly } \\
\text { agree }\end{array}$ \\
\hline Educational contents is fresh and sufficient. & $13.6 \%$ & $32.4 \%$ & $47.5 \%$ & $4.7 \%$ & $1.8 \%$ \\
\hline Teaching pattern is diversified and novel. & $27.5 \%$ & $36.4 \%$ & $33.5 \%$ & $2.5 \%$ & $0.1 \%$ \\
\hline $\begin{array}{l}\text { Teachers are capable, knowledgeable and } \\
\text { skilled. }\end{array}$ & $21.4 \%$ & $35.5 \%$ & $32.6 \%$ & $\begin{array}{c}10.2 \\
\%\end{array}$ & $0.3 \%$ \\
\hline Assessment methods is scientific and rational. & $16.4 \%$ & $27.1 \%$ & $42.8 \%$ & $9.3 \%$ & $4.4 \%$ \\
\hline
\end{tabular}

The survey also found that the respondents did not fully understand the importance of continuing education, 24\% thought it was "unimportant" and 31\% thought it was "normal" (see Fig. 1). Part of the reason may be that promotions and salaries of accountants have little to do with continuing education, with up to $73 \%$ saying salaries have "unrelated" with continuing education (see Fig. 2). 


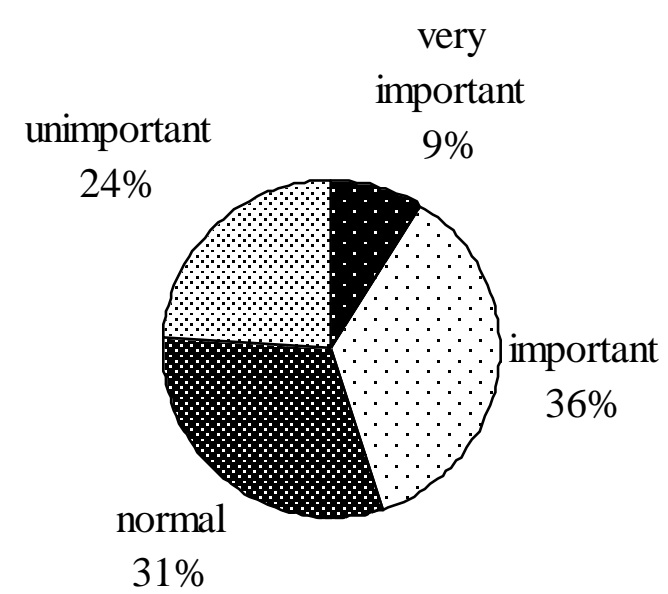

Figure 1. Evaluation of the importance of continuing education for Accountants by respondents

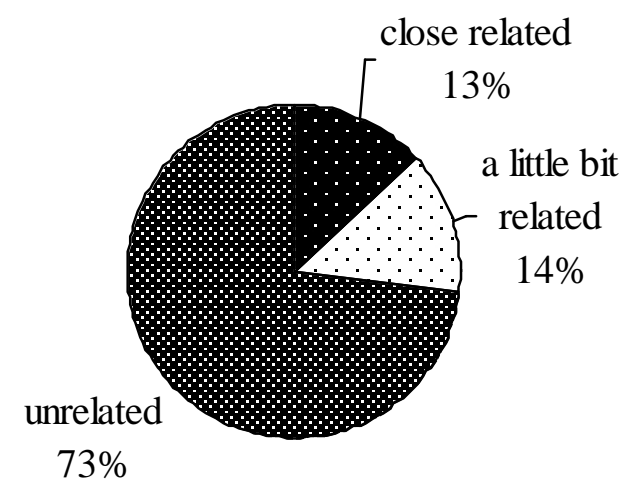

Figure 2. Evaluation of the relationship between salary and continuing education by respondent

\section{Literature References Analysis of Existing Problems}

Insufficient Attention to the Continuing Education of Accountants. Some university administrators do not have a clear understanding of the content and nature of the work of accountants and financial personnel [5]. They regard that accountants in colleges and universities do not need to carry out relevant training for this kind of work. They believe that accountants can learn by themselves in the process of meeting new knowledge. At the same time, the training of accountants will be regarded as an unnecessary procedure that will affect the normal work of colleges and universities. This phenomenon of paying little attention to the continuing education of accountants leads to many problems in the position setting of Accountants in colleges and universities. For example, the number of full-time accountants in colleges and universities is extremely limited; the continuing education and training of accountant relatively small investment in colleges and universities, resulting in accountants can not accept good training and business ability can not be effectively improved.

Lake of the Pertinence in Continuing Education for Accountants. According to the actual situation of the continuing education of Accountants in China's colleges and universities, it often lacks proper pertinence. The continuing education can not proceed from the actual situation of accountants' professional level and responsibility field, and can not continue to combine the work of education with the reality of accountants closely [6]. Each accountant's position is different from his own conditions, but the content of the continuing education is consistent. Therefore, there are serious loopholes in this mode of continuing education, which affects the effectiveness of continuing education, and is not conducive to the promotion of accountants' professional ability. Over time, it hinders the enthusiasm and enthusiasm of the accountants for training. This lack of targeted education is tantamount to waste of time.

Weak of the Evaluation of Continuing Education. According to the evaluation of the continuing education of Accountants in colleges and universities in China, most continuing education use open-book examination [7]. Although some areas still implement closed-book examination, the examination discipline is not serious enough in the examination process. In addition, from the perspective of training institutions, in order to increase the number of students, many institutions are too formal in the examination process. And some organizations only produce questions, but do not carry out examination paper evaluation. This phenomenon has greatly affected the seriousness of the continuing education evaluation work. 


\section{Conclusion}

Continuing education is not only the legal obligation of accountants, but also the fundamental way to improve their professional ability. Only by strengthening the continuing education of Accountants in colleges and universities, it can guarantee the quality of accounting information and promote the development of colleges and universities. Through the analysis of the problems existing in the continuing education of Accountants in colleges and universities, we find that in the continuing education of Accountants in colleges and universities, the financial management departments and training institutions, university leaders and accountants in colleges and universities should set up correct modern continuing education ideas, and the financial departments should strengthen the relevant management of continuing education. The assessment methods of continuing education should be diversified and objective[8]. The training institutions must pay more attention to the effectiveness and pertinence of continuing education training content. And the finance department of government should establish a long-term mechanism for this continuing education.

\section{Acknowledgements}

This paper is sponsored by project fund from Leading Group Office of Jilin Provincial Educational Science (Project Title: Research on the innovative way of continuing education for accountants in Local Universities; Contract NO. GH170612). In addition, it is also sponsored by the grant from the Higher Education Research Institute of Jilin Engineering Normal University.

\section{References}

[1] Information on http://www.moe.gov.cn/

[2] K. Ren: China Collective Economy, Vol. 32 (2016) No.7, p.149-150.

[3] B.Z. Liu: Modern Economic Information, Vol. 13 (2016) No.12, p.387.

[4] J.H. Wu: Economic Vision, Vol. 21 (2014) No.12, p.57-58.

[5] H.H. Teng and N. Huang: Assets and Finances in Administration and Institution, Vol. 8 (2013) No.2, p.200.

[6] J. Tian, Z. Chen and H.Y. Zhang: Modern Business, Vol. 10 (2013) No.35, p.227-228.

[7] B. Clayton and J. Viljoen: Journal of Education for Business, Vol. 65 (2010) No.6, p.255-259.

[8] S.Q. Mao, J.Y. Yuan and H. Chen: Economic \& Trade, Vol. 4 (2018) No.10, p.281. 